\title{
Method single burning item (SBI) for fire hazard of wood constructions
}

\author{
Marina Gravit $^{1}$, Yana Simonenko ${ }^{1, *}$ and Arkady Larionov ${ }^{2}$ \\ ${ }^{1}$ Peter the Great St. Petersburg Polytechnic University, 29 Politekhnicheskaya St., St. Petersburg, \\ 195251, Russia \\ ${ }^{2}$ Moscow State University of Civil Engineering, Yaroslavskoeshosse 26, Moscow, 109377, Russia
}

\begin{abstract}
This research covers fire risk classification for construction materials in the countries of the European Union and a full methodological approach to the assessment of the fire hazard, providing requirements, characteristics, and test methods depending on the field of their usage and functional purpose. Application of fireproof coating and constructive fireproofing are considered to be one of the most widespread ways to increase fire safetyof wood constructions. The need to improve approaches tothe development and application of fireproofing ofwood materials, methodological assessment of their efficiency providing fire safety are also specified. The evaluation of the fire behavior of the fireproofed wood samples has been carried out. Two methods were used to get the results: Russian National StandardR 53292-2009 "Fireproof compositions and substances for the wood and materialsbased on it. General requirements.Test methods" and EN 13823:2003 (SBI) method.The purpose of test using a single source of flame (SBI) also involves an application of the larger selection model than the standard test methods in order to get the results, which are much closer to the full-scale reference phase of the fire propagation.Several conclusions have been made: whether it is possible to introduce European standards for the assessment of the construction materials fire risk to the national practice and incorporation of the requirements stipulated in the similar European regulations to the Russian standards.
\end{abstract}

\section{Introduction}

When determining the functional area and the certification of the construction materials, it is necessary to evaluate their fire hazard. There are different methods to do it, such as test method on combustibility, inflammability, flame distribution on the surface, smoke release and toxicity of the burning products [1]. Fire hazard class of this or that material (KM0KM5) may be defined depending on the values of the standard parameters determined by the experiment. Classification is the basis for the fire prevention rationing of the construction materials usage inside the buildings and structures.

\footnotetext{
*Corresponding author: YannaSimnna98@mail.ru
} 
According to fire risk, all the construction materials are divided into six classes: KM0$\mathrm{KM}$, where KM0 is noncombustible materials, KM5 is the most flammable materials.

In the construction materials classification (table 1), there is the same principle as in the European classification, i. e. the materials with certain fire risk indicators determined by different methods belong to one and the same class [2].

The important aspect of the efficient protection of any building is the fire behavior of the construction materials, whether they provide residents or users of the building with enough time to be evacuated, thereby potentially saving their lives. [3-5]. Dealing with the fire safety of the buildings, European countries follow various legal regulations based on the national traditions and the assessment of the safety level [6].

The main properties defining which Euroclass the product belongs to are as follows: incombustibility, inflammability, flame distribution, heating value, and the product's ability to produce smoke and burning drops. Depending on the final result of possessing certain properties the product is referred to the fire safety class.

Test on fire resistance according to Euroclasses:

Tests of the construction materials on fire resistance.Incombustibility, EN ISO 1182.

Tests of the construction materials on fire resistance.Determination of the thermal potential, EN ISO 1716.

Tests of the construction materials on fire resistance.Construction materials, except for the floor materials, affected by the heat of the gas burner EN 13823:2003 (SBI) [7].

Tests of the construction materials on fire resistance. Combustibility of the construction material undergoing direct fire effect.Part 2: Test with using one source of the flame, EN ISO 11925-2.

Test of the floors on their fire resistance. Part 1: Determination of the fire behavior by IR-source, EN ISO 9239-1.

Therefore, the fire risk of the construction materials is evaluated by rather wide range of the factors.

\section{Materials and Methods}

According to the Russian National Standard R53292-2009"Fireproof compositions and substances for wood and materials basedon it.General requirements. Test methods" [8], the fireproof efficiency of impregnating compounds and coatings for wood is assessed with the laboratory small-scale method. When the material is affected by intensive radiant thermal flux, fireproofing may occur to be ineffective. Examples are known when the samples of wood treated with impregnating fireproof compounds were referred to the materials with the highest fire proofing group (I) according to the Russian National StandardR 532922009. They were characterized by fast flame distribution on the surface during the test using the standard method according to the Russian National Standard 12.1.044-89(item 4.19) as well as EN 13823:2003 (SBI) method.

Within other experiments, the tests according to the Russian National Standard 12.1.044-89 (items 4.20) showed the output increase of the toxic combustion for the wood treated with some effective antipyrens.

In this work, the combustibility of the wood samples treated with fireproof compositions was evaluated. To get the results two methods were used: Russian National Standard R 53292-2009 "Fireproof compositions and substances for wood and materials on its basis. General requirements. Test methods" [8] and EN 13823:2003 (SBI) method [7].

Test samples for the method [7] represent the boards (pine wood) with the dimensions of $1.5 \times 0.5$ and $1.5 \times 1.0 \mathrm{~m}$ with the angle of $90^{\circ}$ (Fig. 1).

These samples were affected by the flame of the gas burner during 20 minutes. As a result, the following parameters were specified: heat release rate FIGRA (W/c), amount of 
heat released while burning THR (MDzh), the length of the flame distribution LFS (m), smoke emission intensity SMOGRA $\left(\mathrm{m}^{2} / \mathrm{s}^{2}\right)$, and the total amount of the emitted smoke $\operatorname{TSR}\left(\mathrm{m}^{2}\right)$ (Fig. 2).

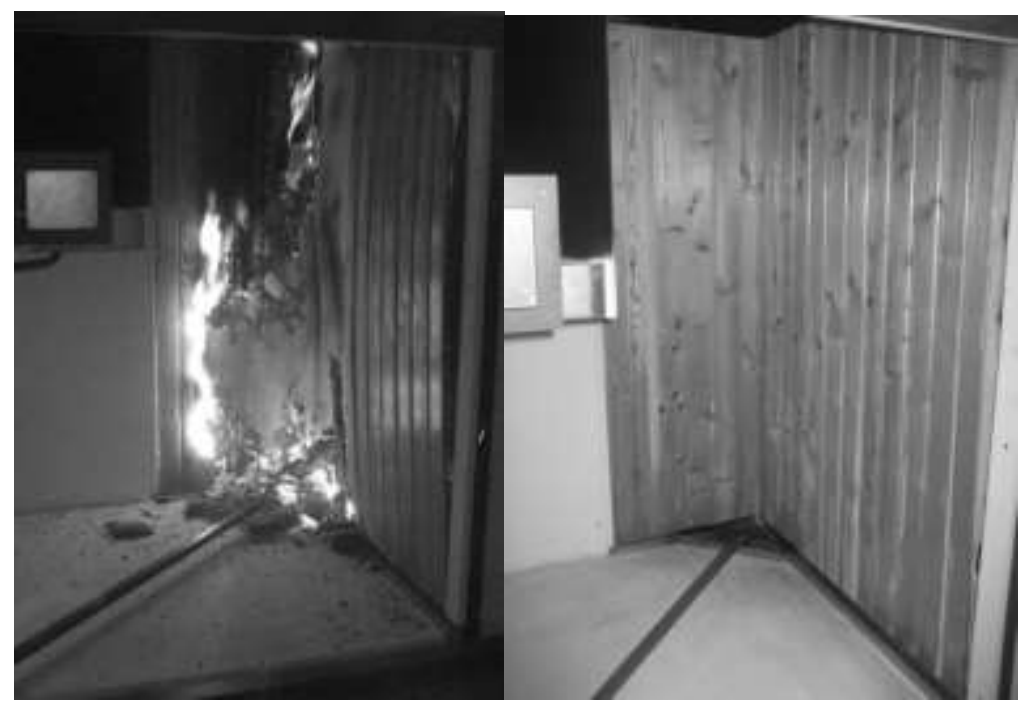

Fig. 1.Test samples.Fig. 2. Samples after the test.

The equipment used in the test method [7] allows obtaining data in the form of graphics for each indicator. It is especially important when determining dynamics of FIGRA increasing or decreasing depending on time of the flame impact (Fig. 3, 4) as well as defining the amount of the emitted THR warmth in various intervals of time.

To achieve the decrease in fire, hazard wood samples were treated with various compositions of varnishes and impregnations the results of which were obtained according to [8] - groups of fireproof efficiency were defined (the group of fireproof efficiency is defined on losses of weight after combustion of standard wooden bar during the set time).

Based on the obtained data according to [7], the class of fire hazard of the tested samples was specified according to the European classification of EN 13501-1:2007. Classification of construction materials and elements of buildings by fire resistance.Part 1.Classification applying the data of the tests on the combustion reaction during the test on fire resistance. [2].

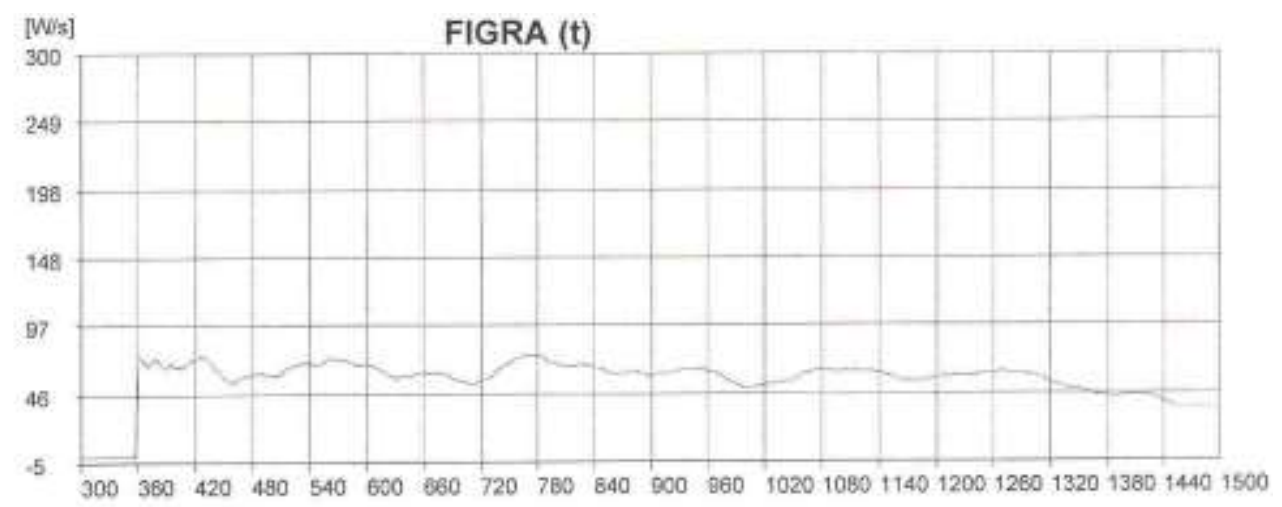

Fig. 3.FIGRA time dependence for composition 3. 


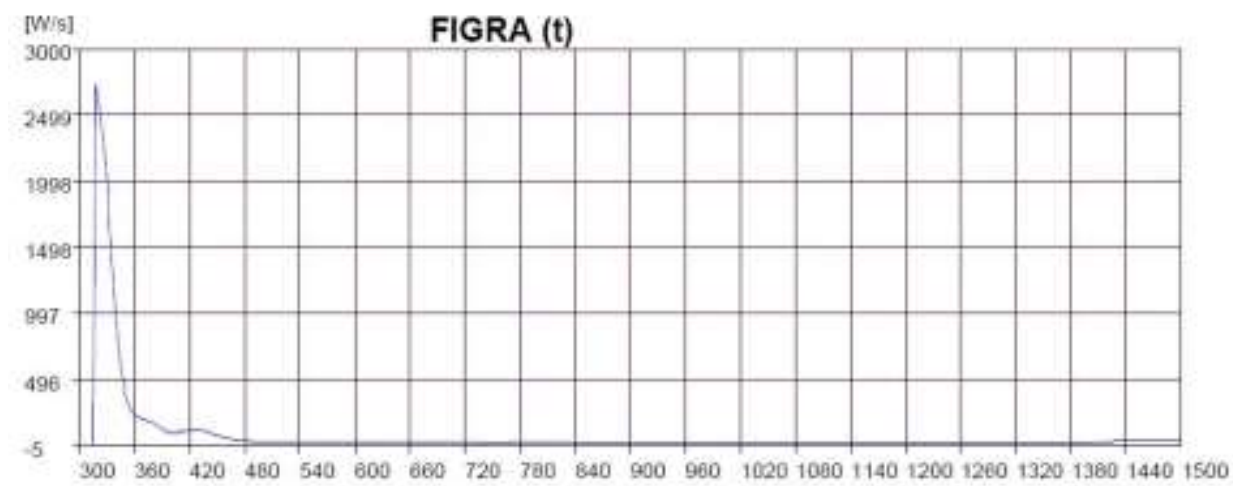

Fig. 4. FIGRA time dependence for composition 4.

\section{Results and discussion}

According to the data provided in table 2, it is obvious that there is no any correlation between the test results based on Russian National Standard R 53292-2009 [8] and EN 13823 SBI [7].

Material with the worst rate in the group of fireproof efficiency shows in some cases the best results at the test based on the EN 13823 SBI method. This fact is due to the limit of the criteria for assessment of fireproof efficiency of the compositions on wood at test in accordance with Russian National StandardR 53292-2009.

Table 1.Assessment results of the fire hazard of the pine wood treated with fireproof compositions.

\begin{tabular}{|c|c|c|c|}
\hline Material & $\begin{array}{c}\text { Group fire retardant } \\
\text { efficiency Russian } \\
\text { National Standard R } \\
53292\end{array}$ & $\begin{array}{c}\text { Test results by } \\
\text { EN 13823 }\end{array}$ & $\begin{array}{c}\text { Class according } \\
\text { to EN 13501-1 }\end{array}$ \\
\hline $\begin{array}{c}\text { Wood (pine) humidity } \\
18 \%\end{array}$ & - & $\begin{array}{c}\text { FIGRA } 0,2=452,39 \\
\text { FIGRA } 0,4=452,39 \\
\text { THR600 }=26,205\end{array}$ & $\mathrm{D}$ \\
\hline $\begin{array}{c}\text { Composition based on } \\
\text { liquid sodium glass } \\
\text { (No1) }\end{array}$ & I group & $\begin{array}{c}\text { FIGRA } 0,2=268,63 \\
\text { FIGRA 0,4 }=268,63 \\
\text { THR600 }=20,101\end{array}$ & $\mathrm{D}$ \\
\hline $\begin{array}{c}\text { Impregnation based on } \\
\text { an aqueous solution of } \\
\text { inorganic salts (No. 2) }\end{array}$ & II group & $\begin{array}{c}\text { FIGRA } 0,2=200,83 \\
\text { FIGRA } 0,4=186,35 \\
\text { THR600 }=21,486\end{array}$ & $\mathrm{C}$ \\
\hline $\begin{array}{c}\text { Composition based on } \\
\text { carboxylate } \\
\text { resin (No3) }\end{array}$ & I group & $\begin{array}{c}\text { FIGRA } 0,2=76,40 \\
\text { FIGRA } 0,4=74,76 \\
\text { THR600 }=11,700\end{array}$ & $\mathrm{~B}$ \\
\hline $\begin{array}{c}\text { Composition based on } \\
\text { urea-formaldehyde resin } \\
\text { (No4) }\end{array}$ & I group & $\begin{array}{c}\text { FIGRA } 0,2=2729,07 \\
\text { FIGRA } 0,4=2729,07 \\
\text { THR600 }=11,712\end{array}$ & $\mathrm{D}$ \\
\hline
\end{tabular}

Thus, comparative study of both national and European systems of evaluation of the fire hazard for the construction materials shows significant differences both in methodological approach and in classification. 
Table 2.Classes of reactions according to the ability to fire construction materials with the exception of floor coverings.

\begin{tabular}{|c|c|c|c|}
\hline Class & Testmethods & Classificationcriteria & Additional classification \\
\hline \multirow[t]{2}{*}{ A1 } & $\begin{array}{l}\text { EN ISO } 1182(1) \\
\text { and }\end{array}$ & $\begin{array}{c}\Delta \mathrm{T} \leq 30^{\circ} \mathrm{C} ; \text { and } \Delta \mathrm{m} \leq 50 \% ; \text { and } \mathrm{tf}= \\
0 \text { (i.e. no sustained flaming) }\end{array}$ & - \\
\hline & EN ISO 1716 & $\begin{array}{c}\text { PCS } \leq 2,0 \text { MJ.kg-' }(1) \text { and } \\
\text { PCS } \leq 2,0 \text { MJ.kg-1 (2) (2a) and PCS } \leq \\
1,4 \text { Mj.m-2 (3) and } \\
\text { PCS } \leq 2,0 \text { MJ.kg-1 (4) }\end{array}$ & - \\
\hline \multirow[t]{3}{*}{ A2 } & EN ISO $1182\left(\left(^{\prime}\right)\right.$ or & $\begin{array}{c}\Delta \mathrm{T} \leq 50{ }^{\circ} \mathrm{C} \text { and } \\
\Delta \mathrm{m} \mathrm{s} 50 \% \text { and } \\
\mathrm{tf} \leq 20 \mathrm{~s}\end{array}$ & \\
\hline & EN ISO 1716 and & $\begin{array}{l}\text { PCS } \leq 3,0 \text { MJ.kg-1 (') and } \\
\text { PCS } \leq 4,0 \text { Mj.m-2 (2) and } \\
\text { PCS s 4,0 MJ.m-2 (') and } \\
\text { PCS }<, 3,0 \text { MJ.kg-1 (4) }\end{array}$ & 一 \\
\hline & EN 13823 (SBI) & $\begin{array}{c}\text { FIGRA } \leq 120 \mathrm{~W} . \mathrm{s}-1 \text { and } \\
\text { LFS }<\text { edge of specimen and } \\
\text { THR600s } \leq 7,5 \mathrm{MJ}\end{array}$ & $\begin{array}{l}\text { Smoke production (5), and } \\
\text { flaming droplets/particles (6) }\end{array}$ \\
\hline \multirow[t]{2}{*}{ B } & $\begin{array}{l}\text { EN } 13823(\mathrm{SBI}) \\
\text { and }\end{array}$ & $\begin{array}{c}\text { FIGRA } \leq 120 \text { W.s-1 and } \\
\text { LFS }<\text { edge of specimen and THR600s } \\
\leq 7,5 \mathrm{MJ}\end{array}$ & \multirow[t]{2}{*}{$\begin{array}{l}\text { Smoke production (5), and } \\
\text { flaming droplets/particles (6) }\end{array}$} \\
\hline & $\begin{array}{l}\text { EN ISO } 1192 \\
\text { 5-2 (8) Exposure - } \\
\text { 30s }\end{array}$ & $\mathrm{Fs} \leq 150 \mathrm{~mm}$ within $60 \mathrm{~s}$ & \\
\hline \multirow[t]{2}{*}{$\mathrm{C}$} & $\begin{array}{l}\text { EN } 13823(\mathrm{SBI}) \\
\text { and }\end{array}$ & $\begin{array}{c}\text { FIGRA } \leq 250 \mathrm{~W} . \mathrm{s}-1 \text { and } \\
\text { LFS }<\text { edge of specimen and THR600s } \\
\leq 15 \mathrm{MJ}\end{array}$ & \multirow[t]{2}{*}{$\begin{array}{l}\text { Smoke production (5), and } \\
\text { flaming droplets/particles (6) }\end{array}$} \\
\hline & $\begin{array}{c}\text { EN ISO } 11 \\
925-2(8): \\
\text { Exposure }=30 \mathrm{~s}\end{array}$ & Fs $\leq 150 \mathrm{~mm}$ within $60 \mathrm{~s}$ & \\
\hline \multirow[t]{2}{*}{$\mathrm{D}$} & $\begin{array}{l}\text { EN } 13823(\mathrm{SBI}) \\
\text { and }\end{array}$ & FIGRA $\leq 750$ W.s-1 & \multirow[t]{2}{*}{$\begin{array}{l}\text { Smoke production (5), and } \\
\text { flaming droplets/particles (6) }\end{array}$} \\
\hline & $\begin{array}{c}\text { EN ISO 1 } \\
1925-2(8): \\
\text { Exposure = } 30 \text { s }\end{array}$ & Fs $\leq 150 \mathrm{~mm}$ within $60 \mathrm{~s}$ & \\
\hline $\mathrm{E}$ & $\begin{array}{c}\text { EN ISO 1 } \\
1925-2(8) \\
\text { Exposure = } 15 \mathrm{~s}\end{array}$ & Fs $<150 \mathrm{~mm}$ within $20 \mathrm{~s}$ & Flaming droplets/particles (7) \\
\hline $\mathrm{F}$ & & No performance determine & \\
\hline
\end{tabular}

Taking into account the test results according to EN 13823 SBI method and the article review [9-17], conceptual provisions on development of the system of assessment of the fire hazard of wood structures, classification, fire-prevention rationing of their application 
in the construction and confirmations of their compliance with fire safety requirements are formulated:

- Improvement of the classification of the construction materials and fireproofing according to fire hazard on the basis of the modern best international practices;

- assessment of the fire hazard of various construction materials, including fireproof materials and coatings, taking into account modern approach and creation of the general databank (from Federal Laws to standards of the enterprises and specifications on construction products) in order to define the range of use inside the premises (building structures) of different functional purpose, confirmation of compliance with fire safety regulations of different levels;

- development and introduction of the ways of experimental determination of speed of fire propagation, specific mass speed of burning out, specific release (consumption) of toxic gases (oxygen), coefficient of smoke emission and other basic data for problems of mathematical modelling of dynamics of the risk factors of the fire, calculation of fire risk and the time needed for evacuation of the people, design of space-planning solutions of escape routes and screen rooms, justification of their geometrical and technical characteristics;

- further improvement of the fire safety requirements to wood structures and fireproof materials ensuring safety of people and non-penetration of the fire about the building on the basis of the modernized classifications and modern ways of research (tests);

- development of the specifications and technical documentation considering climatic conditions and life cycle on site, especially, with mass stay of people and having important state value.

\section{Conclusion}

Fire tests of wood structures showed their fire resistance limits sufficient for use in the construction of buildings (building structures) of various functional purposes. Parameters of carbonization speed of various wood structures are represented.

Introduction of additional evaluation criteria to the tests of fireproof compositions enables to estimate more sufficiently and objectively the fire risk contribution of the construction materials in respect of modern requirements.

\section{References}

1. Russian Federal Law No. 123-FZ of 22 July 2008

2. BS EN 13501-1:2007+A1:2009

3. M.Hjohlman,P.Andersson, P.van Hees,Fire Technology 47(1), (2011) doi.org/10.1007/s10694-009-0128-2

4. A.Frangi, M.Fontana,Proceedings of the Institution of Civil Engineers: Structures and Buildings 163(4),(2010) DOI:10.1680/stbu.2010.163.4.213

5. O.Zybina, M.Gravit,Y.Stein, IOP Conference Series: Earth and Environmental Science90(1),012227(2017) DOI:10.1088/1755-1315/90/1/012227/meta

6. BS EN 13823:2002

7. Russian National Standard R 53292-2009

8. A.S.Etumyan, N.V.Smirnov, V.V.Bulgakov, M.V.Gravit, Yu.S.Ivanov, Materials XXIV of the International scientific and practical conference on problems of the fire safety devoted to the 75 anniversary of creation of institute1, 339-341 (2012) 
9. O.Zybina, M.Gravit, A.Pizhurin,IOP Conference Series: Earth and Environmental Science 90(1),012103 (2017)

10. P.Blomqvist, A.Bergstrand,N.Neumann,P.Thureson,S.Bengtsson,Fire and Materials 2015 - 14th International Conference and Exhibition (2015)

11. M.V.Gravit, O.V.Nedryshkin, O.T.Ogidan, Magazine of Civil Engineering77(1), (2018) doi:10.18720/MCE.77.4

12. M.Gravit, I.Dmitriev, A.Ishkov, IOP Conference Series: Earth and Environmental Science 90(1),012226(2017)

13. P. Murali, V. Sampathkumar, Civil Engineering Journal4(8) (2018) DOI: 10.28991/cej03091122

14. J.Wang,D.Zhang, Y.Zhang, Y. Hu, W.Hu, Journal of Hazardous Materials 362, (2019) doi.org/10.1016/j.jhazmat.2018.09.009

15. Y.Xu,C.Lv, R.Shen,Z.Wang,Q.Wang, Journal of Thermal Analysis and Calorimetry(2018) doi.org/10.1007/s10973-018-7735-4

16. B.A.-L. Ostman, E.Mikkola,HolzalsRoh -und Werkstoff64(4), (2006) doi.org/10.1007/s00107-006-0116-X

17. J.Axelsson,P.Van Hees, Fire and Materials29(1)(2005)doi.org/10.1002/fam.879 